\title{
From Death to Life: The Fiction of Ernest J. Gaines
}

\section{Jerry H. Bryant}

In 1963, The Sewanee Review published “Just Like a Tree," one of Mr. Gaines's first stories. Since then, Dial Press has brought out two novels, Catherine Carmier (1964) and Of Love and Dust (1967), and a collection of short stories, Bloodline (1968). His first two novels are competent, promising pieces of fiction. The five stories in Bloodline are of high quality, confirming the potential of Catherine Carmier and Of Love and Dust. With the appearance of The Autobiography of Miss Jane Pittman, eight years after the publication of his first story, Gaines makes the leap from promising competence to mature achievement. It is, in my opinion, one of the finest novels written since World War II in America and a distinguished contribution to our national literature. Its publication calls for a critical interpretation and assessment of all of Gaines's work, particularly the stylistic and thematic relationships between this latest brilliant novel and his earlier pieces.

I am going to start with what I take to be the weaknesses in the first two novels, but I want to emphasize that whatever I say that is derogatory, in the long run weighs little on the scales of Gaines's total merit. I can think of no other contemporary American novelist whose work has produced in me anything like the sense of depth, the sense of humanity and compassion, and the sense of honesty that I find in Gaines's fiction. It contains the austere dignity and simplicity of ancient epic, a concern with man's most powerful emotions and the actions that arise from those emotions, and an artistic intuition that carefully keeps such passions and behavior under fictive control. Gaines may be one of our most naturally gifted story-tellers. Hopefully, we may look to him for many more years of increasing satisfaction, for he is only thirty-eight years old.

The trouble with having a native talent in an age so self-conscious as ours is that there are too many temptations to ignore that talent and imitate abilities of others who have already succeeded. This temptation especially assails the young and the inexperienced. The Gaines of Catherine Carmier and Of Love and Dust is relatively young and inexperienced, and he succumbs to the power and the achievement of Hemingway and Faulkner. From Hemingway, he borrows the familiar clipped, journalistic sentence structure, understatement and repetition, and simple, concrete diction. These qualities come naturally to Gaines, but when he attempts to implement them through Hemingway, too much of Hemingway and not enough of Gaines remains. Furthermore, underlying the Hemingway style is the Hemingway philosophy, a tough but sentimental stoicism whose 
highest good is the display of individual grace under pressure, the deliberate seeking out and meeting death with courage.

The spirit of Hemingway is inappropriate to Gaines. Gaines's perception of the world may contain some stoicism, but it is a less theatrical stoicism than that of Hemingway, less self-conscious, less colored by a self-indulgent sense of grievance. The inappropriateness of the Hemingway spirit is most obvious when Gaines attempts to capture Hemingway's combination of toughness and sentiment in passages dealing with romantic love:

Maybe what she really wanted was to feel his arms around her, their bodies pressed together, his mouth on her mouth. No, not maybe, this is what both of them wanted. ${ }^{1}$

When he is not imitating, Gaines writes much better than this. His dialogue suffers too:

"You know it's wrong, don't you? Don't you know it's wrong?

All we can do is hurt each other, don't you know that?"

"Say you don't love me, Catherine, and I'll never see you again.

Say you don't love me, and I'll never bother you again."2

Because neither Gaines's talent nor his vision harmonizes with those of Hemingway, it is no wonder that he has incompletely adapted his model's techniques and attitudes to his own. Simplicity, understatement, repetition are all admirable qualities of Gaines's prose at its best-not when they descend from Hemingway, but when they emerge directly from Gaines.

Faulkner has had an even stronger and more pernicious hold on Gaines's abilities. One of the most characteristic features of Faulkner's writing is his sense of history. $\mathrm{He}$ is famous for the way in which he expresses this sense in his long sentences, ranging through the present, the past, the future, through parenthetical remarks and qualifying subordinate clauses, identifying ownership and family ties. The success of these sentences is achieved by his genius for combining the serious with the humorous. He counters his stately evocation of vast historical significance with mocking parody. The vision of man such sentences convey is that of a creature at once dignified and noble, and mean and ignominious.

It does not work this way for Gaines. "One summer afternoon," he writes in Catherine Carmier, "Robert Carmier rode up to the plantation store (the store was still being managed by the Grovers then) and asked Mack Grover for the house. (Antoine Richard, who was at the store, brought this version of the story into the quarters.)" (p. 8) In the first place, these sentences are too short to convey the great tides of history we find in Faulkner. More important, Gaines does not have Faulkner's particular sense of historical and human ambiguity. What in Faulkner is a combination of opposites that elicits the laughter of the gods, in Gaines is youthful seriousness lacking in depth. This seriousness leads him to respond to another fatal temptation: "explaining" the significance of his story. Too often we get from the characters interpretations of the action that 
should have been left unspoken. For example, in Of Love and Dust, after eliciting from the reader an ambivalent judgment of rebellious young Marcus Payne, Gaines has his narrator, Jim Kelly, settle our minds with a positive evaluation. These are the shortcomings of an inexperienced writer lacking in confidence, who does not trust the concrete action to convey its own meaning. Faulkner leans in this direction too, but his aim is to intensify the ambiguity he perceives in the world. He generally uses the context of his explanations to undercut their validity. The explanations in Catherine Carmier and Of Love and Dust, though expressed by the characters in context, seem to come from Gaines himself.

It is understandable how Gaines could have put himself into such deep debt to Hemingway and Faulkner. Hemingway's popularity reached a peak in the 1950's when Gaines was going to college. And Faulkner is, like Gaines, a native Southerner. Few Southern writers who write about the South can escape his influence. But of course Gaines need imitate no one. The five stories in Bloodline are proof of this. Showing very little awareness of either Hemingway or Faulkner, in this collection Gaines advances stylistically from his first two novels, making greater use of the dialect he knows so well-that of the Louisiana bayou country where he grew up-and introducing a greater sharpness and liveliness in the language of his narrators. His phraseology takes on the quality of that of the black preacher, and derives from the poetic language of black folk forging their perceptions of the world with simple, unlettered directness. In "Just Like a Tree," old Aunt Fe eases

back on the bed-calm, calm, calm. (p. 249)

Her passing will be like the cutting down of a beautiful old tree, which leaves

a big hole in the ground . . . and you get another big hole in the air where the lovely branches been all these years. (p. 236)

A character speaks of the fate of old people in the face of growing black unrest and increasing civil rights demonstrations:

A big wind is rising, and when a big wind rise, the sea stirs, and the drop o' water you see laying on top the sea this day won't be there tomorrow. (p. 245)

There is repetition, understatement, simplicity, and poetry here, but it is Gaines's, not Hemingway's.

Because the stories in Bloodline were written before or during the composition of Catherine Carmier and Of Love and Dust, we might assume that the difference in the quality of their styles is due to a predilection in Gaines for the short rather than the long narrative. The disproof of this assumption comes with The Autobiography of Miss Jane Pittman. Here Gaines finds his true voice. I can think of no other novel by a black author in which a black Southern dialect is so successfully sustained over a long narrative. What is most impressive is the dia- 
lect's authenticity. Artists in all media have always been fascinated by the art and language of the folk. Theocritus, Virgil, Longus, Chaucer, Spenser, Wordsworth-all have attempted to render the spirit of the common speech of simple people. Keats and Yeats adapted the form of the medieval folk ballad to their own artistic purposes. In each case, however, the adapting poet was educated in a culture and a language widely different from that of the poets whose forms they tried to imitate. The ballads of Keats and Yeats are "art" rather than "folk" ballads, and the pastorals of Virgil and Spenser reflect what educated, sophisticated men assume to be the simple expressions of country life rather than exact renderings of that life. Gaines bridges the gap between the folk artist and the cultured artist of formal education. He is both. His is not, therefore, an "art" narrative, but an authentic narrative by an authentic ex-slave, authentic even though both are Gaines's inventions. So successful is he in becoming Miss Jane Pittman, that when we talk about her story, we do not think of Gaines as her creator, but as her recording "editor."

Miss Jane's art is that of the primitive minstrel. Her interests are events and her feelings about those events rather than motives and psychology. She is a completely honest reporter, who does not like "retrick." She throws away good lines and ignores contrived climaxes. Her narrative runs evenly, with few peaks and valleys, as if her vantage point of a century of living has brought her a peace and serenity which erases the turbulence in her recall. Her contempt for literary self-consciousness is the contempt of the person for whom talking is neither a recreation nor a polemical device, but a very precarious means for communicating precious values from one person to another, from one generation to the next. The world we view is Jane's world, but many of the details come from her friends who gather around the imaginary tape recording of Gaines's imaginary "editor," so her story is a communal effort. Jane is, therefore, for all her powerful uniqueness, a representative character. And her story is a representative story, the collective account of the collective black since emancipation, told by Jane when she is 110 years old, just a hundred years after she is freed from slavery.

All of these aspects of the novel produce Gaines's most mature work. Only the cumulative effect of reading through the entire chronicle can convey the substance of Gaines's stylistic achievement. But a short sample can suggest the quality of Jane's language. The following is her comment about the collapse of Reconstruction and the cruelty with which lawless bands of whites treated those blacks who sought to make a living by farming their own small plot of land. Such groups, says Jane,

rode all over the state beating and killing. Would kill any black man who tried to stand up and would kill any white man who tried to help him. Just after the war many colored people tried to go out and start their own little farm. The secret groups would come out there and beat them just because their crops was cleaner than the white man's crop. "What you growing there, Hawk?" they would ask him. "Corn, Master," Hawk would say. "That look like grass out there to 
me, Hawk," they would say. "But 'fore day in the morning I surely get it out-if the Lord spare." "No, you better start right now, Hawk," they would say. Then they would make you get down on your hands and knees and eat grass till you got sick. If they didn't get enough fun out of watching you throw-up, they would tie you to a fence post or to a tree and beat you. "Tomorrow night we come back again, Hawk," they would say. "And you better not have no grass out there, you hear?" Or, "Tomorrow night we come back and you better have some grass in that field, hear, Charlie?” (p. 53)

From the beginning, Gaines has worked to put into an appropriate form his own sense of history, a sense which has both dictated and arisen from his central subject, the blacks and the whites who live in and around his imaginary town of Bayonne, near Baton Rouge, and who work the land of the plantations that still survive. Gaines has the special feeling for these people and this land that comes from having grown up among them, and having absorbed the quality of their lives without exercising any analytical selectivity as to what he absorbed. Thus, his feelings are strongly attached to the sheer physical texture of this country, and it pervades his fiction: the hot summer sky filled with a hazy sun; the freezing, sleet-ridden days of winter; the monochromatic hues of a brilliantly white sky meeting a brilliantly white earth; the winter darkness in whose heavy overcast the distinction between the earth and the sky are obliterated. Gaines has the intuition of D.H. Lawrence and Thomas Hardy. Like them, he feels a permanent spirit residing in the land, which transcends time and space. His characters are born with the past in their bones, and their lives, whether they stay or leave this place, are dominated by it-this "place" in which the past is embedded.

It is not surprising that Gaines failed effectively to cast these responses in forms created by Faulkner. Faulkner sees in the past an admirable simplicity and strength, whose resting place is the ancient wilderness. That past is not without its evil, but by far the greater evil for Faulkner is the intrusion of the new into the old, to the destruction of the former. Gaines's conception of the past does not simply and diametrically oppose that of Faulkner. Had it done so, he would not have mistaken Faulkner's forms as appropriate vehicles for his own fiction. Gaines's vision entails a deep conflict of values. In the past, he sees much to love and to cherish, especially in the figures of his old "aunts," whose lives are manifestations of that past. For example, Aunt Charlotte in Catherine Carmier and Aunt Margaret in Of Love and Dust, patiently submit to the slave mentality and the absolute power of the whites, and find their satisfaction and contentment in that submission. Submission is virtually a religion for them. They find the threat of change not only repugnant, but full of forebodings of cosmic doom, the disruption of the heavens, and the onset of chaos. Their own lives having been so precarious and unsure, they cling to the nearest and most accessible certainty, the Southern code of de facto slavery. They are strong and courageous, however, and fiercely determined to survive. For them Gaines has the love of a son for his mother, a love so ambivalent as to be painful, divided between gratitude for the mother's unconditional love and always welcoming arms, and re- 
jection of the dependence and love which means destruction of dignity and pride, indeed, of one's very self.

In the present Gaines sees much to reject, especially as it appears in the figures of some of his rebels against the old order. Jackson Bradley and Marcus Payne, for example, from Catherine Carmier and Of Love and Dust respectively, make overt attempts to bring down the old structures. While such attempts may be desirable in the abstract, in these particular cases our approval of them is deeply equivocal, as is Gaines's. Jackson is too strident an accuser of the plantation world, concentrating too much on condemning it while justifying himself and insisting upon his own innocence. Marcus looks for grievances, too, and is quick to find them. His means of seeking redress, however, are ill-conceived and hasty, and endanger not only himself but other innocent people.

Gaines is torn between his love for the persons of his "aunts" but a rejection of their submission to the past, and a rejection of the persons of his "rebels" but approval of their defiance of the Southern code. Consequently, in Catherine Carmier and Of Love and Dust, his main theme is the conflict between changing the inheritance from the past and resistance to that change. He cannot follow Faulkner in an affirmation of the old, nor can he turn away from Faulkner in an affirmation of the new. He is left with a deep split. Faulkner's sense of history tells him that the new will inevitably replace the old. The acceptance of this inevitability makes it possible for Faulkner to shape his controlling irony, the clash between his nostalgic wish to perpetuate what is good in the past and his realistic recognition that the present denies him that wish. This kind of paradox, since it is embedded in nature, is subject to satisfactory fictional balance. For Gaines, however, the past with its implications of slavery cannot be thought of as worth preserving. Nor can the present with its implications of thoughtless, self-centered revolution be thought of as repugnant enough to reject.

In Catherine Carmier and Of Love and Dust, Gaines has worked out neither an ethical nor an esthetic resolution to these contradictions, that satisfactorily reflects his own intuition. Instead, he invests the two novels with a classical inevitability similar to Faulkner's, except that for Gaines the victor is the past, the world of slavery. Jackson Bradley loses his beloved Catherine and with her, as he puts it, new life and fresh air. Marcus Payne loses his bid to get revenge against Sidney Bonbon, the white plantation overseer, by running off with Sidney's wife, Louise. It is as if the will of the gods supports the Southern code, as if some transcendent force embraces the destiny of all the characters and no puny human can thwart that destiny. Those who struggle are defeated. The Aunt Charlottes and the Aunt Margarets have tuned into the controlling forces, but in their submission to them, they too are defeated. All of the characters seem to be victims, either unable to bring about salutary change or determined to resist change.

These novels suggest that the past is too strong to fight against it. From this, we can infer their significance. They are inventions of images of failure, seeing and experiencing which the reader may better know the true nature of his condition. This is pessimistic determinism, similar to the assumptions of Hemingway and Faulkner, and it does not quite embody Gaines's own convictions. These 
novels tell us what they do because of the disharmony between Gaines's intuitive vision and the vision he hammered out to fit his literary models. His intuitive vision is that, though much of men's lives may be determined, in the instance of slavery the slave past must not be either valued or preserved, and need not be. This vision says that there is no god-like force preventing us from bringing about change. In Of Love and Dust, Gaines shows signs of liberating himself from determinism. Presiding over the fates of Bonbon and Marcus is Marshall Hebert, the white owner of the plantation on which the two men work. Hebert manipulates them for his own benefit, and wins. But Hebert is not a god, and James Kelly becomes aware of this in the course of the novel. Hebert is vulnerable. And because he is, the possibility of destroying his power and introducing change is no dream or illusion doomed by irresistible necessity. However many reservations Gaines has about Marcus as a rebel, he has Kelly conclude that Marcus, in his defiance of the Southern code, is to be admired for "starting something that others would hear about, and understand, and follow." (p. 264)

The increasing maturity of Gaines's style is an index to the increasing clarity with which he perceives his theme. Thus, in Bloodline, not only does he have his style under better control than in his first two novels; he also works out an effective metaphor, whose form expresses his conception of history, the possibility that the present may work to make the future better than the past. Very generally, the metaphor is organic life, for which growth and change are the signs of life's greatest strength and highest good. In Bloodline, each of the stories represents a stage of growth, in this case the growth of the black man in a black community toward a courage strong enough to fight a repugnant past in order to bring about a better future. The first story, "A Long Day in November," is about the failure of six-year-old Eddie spiritually to be born into the process of growth. His world is cold and wintry; money is scarce, pleasures few, and light and warmth are in short supply. It is not this world, however, that blocks the commencement of Eddie's growth. It is the reversal of the roles of his parents. His mother Amy has the strength and determination his father should have. But Amy does not use her strength to help Eddie face his world, but to protect him from it. As the story closes, Eddie is back in bed, where he began the story, essentially unchanged, luxuriating in the protective warmth of the covers and fantasizing daring deeds which would take a courage he has not yet learned.

The growth process does not start until the next story, "The Sky is Gray." Octavia, like Amy, is strong and determined, but unlike Amy, she teaches her son James to meet the world with courage and dignity. "You not a bum," she tells James as she orders him to put down his coat collar even against a freezing drizzle, "you a man." Procter Lewis, the nineteen-year-old narrator of the next story, "Three Men," whose title picks up the theme of "The Sky is Gray," carries the growth process another step. Convinced that if he allows a powerful white man to secure his release from jail he will never again belong to himself, Procter determines to refuse any such offer, hoping to acquire by such a refusal the awareness, self-dignity, and strength that Octavia sought to inculcate in James. To acquire these manly qualities is inherently valuable and desirable, but it also means a growth of immense importance to the collective black man. Such quali- 
ties prepare him to contribute to the growth of his people by assuming the courage necessary for trying to destroy lingering slavery. This is precisely the aim of Copper Laurent, the firebrand mulatto son of the late Walter Laurent, in the title story "Bloodline." Copper returns to his father's plantation, where ten years before he had been treated like a slave, without any rightful claims as Walter's son. He proclaims himself a "general," and announces that he plans to lead his "army" not only against those who are denying him his just inheritance, but those general rapists, murderers, and plunderers of his people. Copper may be a little mad, and Gaines may have his suspicions about him, but his vitality injects into the sick atmosphere of the decaying Laurent plantation the irresistible strength of health and confidence in the future.

The growth process depicted in these stories culminates in "Just Like a Tree," which is ironic, since of the work I have been discussing it is one of Gaines's first pieces. A young black militant has become active in the civil rights movement, and in doing so, he has endangered the lives of many of those he loves, including Aunt Fe. One of Aunt Fe's nieces decides to bring the old lady North with her to live. Before she leaves, Aunt Fe's friends gather to say goodbye. Most of them resent the young militant for the same reason many of the blacks in Of Love and Dust resent Marcus, for disrupting the superficial calm of their precarious lives. They are all sceptical and afraid of change. But this rebel is no Marcus Payne. He dislikes what he is doing, knowing that it causes trouble for the people he loves. But he cannot give it up, for he is riding a wave of pride and strength and determination. He approaches his participation in the struggle for freedom fully aware that it is a sword that cuts two ways. He commits himself having decided that his belief in change outweighs the dangers change implies.

Aunt $\mathrm{Fe}$ belongs to a generation that cannot follow its young into the new world. She can neither go North and leave the land she has spent her life on, nor stay on that land in her old situation. She does not, however, like Aunt Charlotte and Aunt Margaret, warn her young descendant to beware the wrath of the gods lest he be destroyed for disobedience. Her time has come and she knows it; she does not attempt to preserve it beyond its term. She crawls into her bed the night before she is to leave, and dies. With her death, Gaines completes a natural cycle, which the stories in Bloodline trace, the entrance of the new, the exit of the old, the death of the past and the birth of the future. In this metaphor, Gaines resolves his ambivalent attitudes toward his "aunts." We may lament the passing of Aunt $\mathrm{Fe}$, but we cannot deny the validity of the young rebel's commitment and the hopeful possibilities of the future for which he is risking both himself and his brothers and sisters. This natural cycle does not lock man into the tragedy of death and the destruction of a valuable past. It supports life, and works to the advantage of the blacks who pattern their lives after its forms.

Bloodline shows Gaines struggling to reconcile his love for his "aunts" and the past they belong to with his rejection of that past and the affirmation of the "rebel." He achieves that reconciliation by examining the process through which the black male acquires the strength and the courage to attempt to modify the 
past. What is lacking in the process expressed in Bloodline is the female element, which until now Gaines has seen merely as the determination to survive and associated it with submission to the past. In The Autobiography of Miss Jane Pittman, he introduces into the metaphor of Bloodline the female element that was lacking, and brings that metaphor to its completion. His sight clearer and his confidence stronger, he abandons the melodramatic superstructure of classical doom in his first novels and turns to the simple, authentic earnestness and understatement of Jane. She is a transformed version of Aunt Charlotte, Aunt Margaret, and Aunt Fe. In her new manifestation, she is both a repository of womanly endurance and a vehicle for the change sought by her men. What has been an unresolved clash between the male and the female, and the new and the old, becomes in Miss Jane Pittman a dialectic of re-enforcing opposites which work for life.

The form of Jane's narrative fits Gaines's theme perfectly. Like the separate stories in Bloodline, each episode in Jane's story marks a stage in the growth of Jane's life and that of the collective black which she mirrors. The first episode is an account of her spiritual birth, in which two bands of soldiers, one Confederate, one Yankee, stop to rest at the plantation where Jane is a ten-year-old slave. The Confederates are weary, hungry, defeated; and they treat Jane with the bitterness of the vanquished. The Yankees are ebullient, optimistic, full of victory, and thoughtful of "Ticey," Jane's slave name. From one of these Yankees, Corporal Brown, Jane takes a new name, Jane Brown, and symbolically is born into freedom. Later, when she leaves the plantation with a group of ex-slaves, she will see them do the same thing, slough off the old and put on the new.

These acts of birth contain a certain amount of exhilaration and hopefulness. But they also contain depression and disappointment. Like the North as a whole, Corporal Brown professes to make Jane free simply by giving her a new name. He excites in Jane, as the North did for all Southern blacks, a dream of freedom and equality that are synonymous with the North. Thus, when the war ends and they are freed, Jane and her companions embark upon a quest for freedom, associated in their minds with an actual place. In Jane's case, it is Ohio, the home of Corporal Brown. But Jane soon realizes that, as a gentle white lady tells her, "there is no Ohio." Gaines has always been moved by the gap between this dream and the reality. Marcus and Louise intend to go North where they supposedly will be free of the prejudices of the Southern code. Aunt Margaret tries to warn them that there is no such North, but Marcus refuses to listen to her. Jane learns for herself, and something more besides. For all the bitter disappointment engendered in the black by the North's unfulfilled and irresponsibly made promises, something of great value is achieved by them. Jane and her people develop an unprecedented impulse toward growth and freedom. More important, Gaines suggests that the only way Jane can complete her quest is to remain in the South.

In other novels dealing with blacks in an oppressive white society, Jane's resigned decision to stay in Louisiana would be the signal for either the pessimistic ending of the story, or the beginning of a detailed account of further outrages committed against the black by the white, an account cast in the voice of 
social protest. The absence of this familiar note in Jane's narrative is one of the things that makes The Autobiography such a milestone in American fiction. Gaines does not avoid having Jane report white atrocities, but he does not allow her to use the propagandistic and sociological stridency that characterizes so many earlier novels.

The second main episode depicts the first attempt of the freed slaves to test their freedom. It is a tragic failure, but it is not a dead end. Before the little band leaves the plantation, they conduct an archetypal discussion, in which emerge the original lines of separation between the young, hot-headed militants, and the old conservative compromisers. The conservative position is expressed, not by one of Gaines's "aunts," but by old Unc Isom, who tries to persuade the younger blacks to use caution:

"You telling us to stay here?" somebody young said.

"Them who want stay, stay," he said. "Them who must go, go.

But this is no time for weeping. Rejoice now."

"We leaving out," somebody young said. "If the old people want stay here, stay. We free, let's move."

"You free from what?" Unc Isom said. "Free to do what-break more hearts?"

"Niggers hearts been broke ever since niggers been in this world," somebody young said." (p. 17)

Unc Isom argues that what is past cannot be helped, and that to demand a redress of past grievances is futile. He says that he is talking wisdom. The young reject his wisdom and move on, Jane among them.

Their decision is fatal. That night, deep in the swamp, they are attacked by a band of outlaw whites, and everyone but Jane and six-year-old Ned is murdered. They cut themselves off from the protection of the plantation and find only death in freedom. They are like children; unused to the responsibilities of independence and intoxicated by their new sense of identity, they do not submit easily to the social imperative of making voluntary concessions. They squabble; they fight; a "slow-wit" tries to rape Jane. They cannot afford such conflict when they are so vulnerable to enemies. When darkness falls, Big Laura, their leader, prepares to light a fire. Silently, everyone gathers around her while she strikes the iron against the flint, draws sparks, starts the flame. It is a fine scene. But this first assertion of black freedom, in which the blaze of consciousness defies the dark swamp, serves only to expose them, and they are killed.

But something of the fire remains. The massacre is not an unequivocal disaster. Little Ned is Big Laura's son, and he has been made the custodian of the flint and the iron, the instruments of light and warmth. They become precious symbols for Ned and Jane. Jane's survival is also significant. Big Laura is the original black mother, whose courage, determination, and stamina transfuse blood-strength into her people. But all of her strength is not sufficient to save the little band. The reason it is not is suggested by the pairing off of Ned and 
Jane. Jane, only a ten- or eleven-year-old child herself, aiso suifers from a body stunted and sterilized by slavery. But her spirit compensates for what she lacks physically. Jane takes from Laura the position of the black mother, and, in caring for Ned as a foster child, demonstrates her willingness and ability to assume the responsibility for succouring and preserving the race. Big Laura had to fail, for she tried to combine the male's explosive strength and drive toward dignity with the female's instinct for preservation and longevity. In Ned and Jane, these qualities are properly divided, though not separated or conflicting. Thus, from the slaughter of the innocents, Jane and Ned emerge as the bearers of a new consciousness, of flint and iron, of manhood and motherhood.

From here on, Jane becomes the preserving woman and Ned (together with Jane's other men) becomes the explosive, courageous male. The several main episodes that constitute the rest of the novel grow out of this relationship. Of these, the pivotal one is that in which Jane marries Joe Pittman and accompanies him from central Louisiana to a ranch near the Texas border, where he has taken a job breaking wild stallions. This is dangerous work, and eventually Jane's fear for his life activates her preserving instinct. When a great black stallion is captured and Jane sees death waiting for Joe on the horse's back, she sets the great beast free. It is impossible, however, for her to protect Joe, just as it is impossible for Aunt Charlotte and Aunt Margaret to protect Jackson and Marcus. It is fortunate that it is so. The character of Joe is a real breakthrough for Gaines, representing a possibility he did not quite formulate in his earlier stories. Joe is the archetypal rebel, but one with whom Gaines can go along unequivocally without sacrificing respect for his old "aunts." Joe is their praiseworthy counterpoint. Echoing Wilson in Hemingway's "The Short Happy Life of Francis Macomber," Joe tells Jane that every man signs a contract when he is born, accepting death as the basic condition of life. If his life and his death are to have any substantial meaning, he must pass his life doing in the best way he can whatever he can do best. In Joe we see the emergence of black manhood, which, in accepting the possibility of death, brings freedom and self-respect, which cannot be achieved by following the pleas of the protective black woman.

The stallion is the force of nature, with which man must voluntarily struggle if he is to make his life worthwhile, if he does not want to become a passive slave to himself and his fears. The tragedy in this relationship is that these forces must eventually break each other, even though to be so broken is, especially for the human, a precious honor. When Joe goes after the stallion and dies in attempting to recapture it, he fulfills his potential. He dies in freedom, grandly and nobly. Jane would rather have him alive and less vividly charged with intensity than have him dead and beyond her arms. We can sympathize with her, and wonder if Joe's commitment to his leviathan job is worth what it returns, whether there is not something terribly wasteful in this warfare between great powers, a squandering of marvelous energy. Yet, even Jane knows without doubt that Joe will never be replaced in her life. His existence shines with the glow of true mettle, enlivens Jane with its display of courage. He is a man. And while he shortens their years together by meeting the obligations of his manhood before 
his obligations to her, neither she nor we could value him nearly so highly had he done it differently.

In this episode, Gaines shows us that death lies constanly across life, and that the confrontation between the two frequently gives life meaning. Joe's struggle with the stallion is analogous to the fire lighted by Big Laura in the swamp. Both are assertions of the black presence against a world that would extinguish that presence. Both contain death because that assertion makes them vulnerable. Even so, the assertion is supremely valuable. All of this sounds like Hemingway. But Hemingway stops with the value of individual assertion. Gaines goes further and suggests that the individual assertion is the value-giving booster to the longevity carried by Jane, the black woman. From that assertion, the black race absorbs intensified life.

Ned inherits the spirit of Joe. Just before Jane goes with Joe to west Louisiana, Ned is forced to run away to Kansas for having joined a black activist movement. Jane makes no secret of her desire that he stay and give up the dangerous activism. But he goes, unable at this point either to die for the cause or to submit as Jane wishes him to do. Ten years after Joe's death, he returns, and begins to preach the words of Frederick Douglass. Work together, he tells his people, but do not condemn all whites. Walk with dignity and do not be afraid to die. We sense that, had not Joe Pittman demonstrated the possibilities, Ned could not have acquired the courage he needs. Joe did not defeat death, but he defeated the fear of it, and for the black man that is the important thing. The new Ned is the spiritual son of Joe. If one must die, he says, echoing Joe, "wouldn't you rather die saying I'm a man than to die saying I'm a contented slave?” (p. 83) And Ned does die, at the hands of a Cajun hired by whites for the job.

Joe and Ned illustrate two of the forms freedom and the pursuit of it take. Both are based on personal courage. Joe faces nature; Ned faces a social system. Joe faces natural necessity in a struggle that ennobles himself and his antagonist. Ned faces a degenerate, demeaning artificiality, a social apparatus that clothes its neurotic fears and mean weaknesses in piety and righteousness. Joe's struggle is universal, the great model of other specific instances. Ned's struggle takes its form from the larger universal. Joe's is an act performed in freedom. Ned's is an act in which freedom must be torn from an oppressive society.

Over half a century after the death of Ned, Jimmy Aaron drives home the importance of Joe's and Ned's example. He returns to his native country around Bayonne as the point man for a civil rights organization. As in Of Love and Dust, the blacks on the plantations are frightened and slightly angered by Jimmy's defiant intentions, though he is no hot-head following ill-conceived plans. But Jimmy manages to win many of them over, convincing them to march in a demonstration he has planned for execution in Bayonne. The morning of the march Jimmy is killed by the local whites. The scene in which the plantation blacks gather to start for Bayonne is the climax to all of Gaines's work and thinking to the present. Jane herself has agreed to participate, indicating the profound change she has undergone in these last few years of the century she has been describing. When the news of Jimmy's death arrives, the gathered blacks go through several minutes of uncertainty, made more difficult by the fact that the white plantation 
owner, Robert Samson, has come to dissuade them from going. There are now, however, more Joes and Neds and Jimmys. Alex Strut steps forward to declare his intention of going into Bayonne to rendezvous with Jimmy's spirit. Still the group hesitates, and then Jane speaks: "I will go with Alex."

With these words, Jane heals the old split between the old and the young, and brings the leading male and the following female into harmony. She has, like the classical black mother, sought to teach her men the protective coatings of obedience and submission. More than that, she has borne one of the essential principles of life, continuity and survival. She has agonized and grieved over the death of her men, but she has never given up nor lapsed into despair. Now she turns onto a new path. She does not counter Alex's determination to go into Bayonne with the advice of Unc Isom or Aunt Charlotte or Aunt Margaret. She joins her longevity with the intensity of Alex. Probably Alex will die, but if he does, as have Joe, Ned, and Jimmy, it will be in the service of the black race's life principle.

The male and female are equally important. The woman preserves, the man makes worthwhile what she preserves. The longevity of the woman contains no vivifying intensity of honor and self-respect and freedom (a generalization from which Jane must be excepted). The explosiveness and intensity of the male contains too little longevity for its value to be satisfactorily grasped. Only when the longevity of the woman and the intensity of the man merge can there be anything like worthwhile life, can the black look forward to a transformed existence.

There is also a lesson in this concept of life and growth for the white American. Robert Samson, the white plantation owner, attempts to prevent his black workers from going into Bayonne. He represents a dead culture. He is one of the last of a long line of white Southerners who have maintained an inflexible resistance to change and growth. Just as Southern whites fought for the re-establishment of a white supremacist rule after the Civil War, so do they fight for its perpetuation in the face of a growing civil rights movement. Just as Colonel Dye takes over the Bone plantation, on which Jane works, upon the collapse of Reconstruction and orders the black hands either to accept the return of the old order or get out, so does Robert Samson tell his black workers that he will throw anyone out of the house he occupies on Samson land if he participates in the Bayonne demonstration. Colonel Dye is an accurate forecast of Robert Samson. Between them there is no growth. While the whites have sought to hold the line, they have been dying, and while the blacks have died in the struggle against containment, they have been growing into a new life. The Southern white, unexercised in movement and risk, has allowed his muscles to atrophy and his energies to dissipate.

The consequences of the white's failure to grow are made clear in the episode which precedes and prepares for the final confrontation between Jane and Robert Samson. Tee Bob Samson, Robert's son, contains the potential for a new white man, but the atmosphere he lives in is airless and his potential is stunted. In a significant reversal from Catherine Carmier and Of Love and Dust, white Tee Bob falls in love with Mary Agnes LeFabre, black. Mary Agnes knows that 
Tee Bob's origins and the culture they both live in absolutely deny any success for Tee Bob's love. Tee Bob, however, like a white Jackson Bradley or Marcus Payne, persists in the belief that the old rules can be transcended by love. For the Southern white, however, there can be no such transcendence, no change, no growth. Tee Bob searches for some break in the container of his culture that hermetically seals him into stasis. Finding none, he commits suicide, for he cannot live without new air.

Like Joe and Ned, Tee Bob presses against an antagonist. Ironically, the class to which he belongs, which maintains nearly absolute physical power over the black man, cannot give Tee Bob any strength. His opponent is in a sense himself, and he dies by his hand. Wise old Jules Raynard, Tee Bob's "parrain" and an old friend of the Samson family, is the kind of man upon whom a new South might be based. He understands that Tee Bob's death is the result of cultural stagnation, for which everyone, including Jane, is to blame. Tee Bob, he says, had to pay for the sins of them all. He does not mean that Tee Bob is an instrument of salvation, through which the sinful may be relieved of their sins, but that he is the inevitable consequence of their sins-the failure to solve racial differences and enter into a new cycle. Tee Bob's literal death prefigures Robert Samson's symbolic one.

Whether it is intuitive or learned, Gaines's perception of the world resembles that of a biologist, who sees each living organism passing through time, occupying stages, crossing boundary lines into new and unfamiliar territory. Organic life is postulated on the oscillation between life and death, and these are the realities which Gaines fastens onto. The two states transmit to each other a vitality, which, when fused in the unity of the organism, presuppose growth, the sine qua non of life. Out of death grows life, which spreads through time to the edge of its identifiable being. If that being cannot tolerate the leaping of its own boundaries, or lacks the strength to make those leaps, it must die without hope of new life. If it dares to make that crossing, it snatches-from the death implied in the crossing-new life. Similarly, the female impulse toward survival and the male impulse toward brief but vivid intensity have, as Gaines suggests in The Autobiography of Miss Jane Pittman, promoted growth in the collective black, the metaphor of whose unity is the living organism. This conviction Gaines drives home in the last sentence of Jane's chronicle. Standing face to face with Robert Samson, the embodiment of a hundred years of white resistance to change, Jane, the embodiment of a hundred years of black growth, pauses in her move toward Bayonne and the demonstration. "Me and Robert," she says, "looked at each other a long time, then I went by him."

This sentence may become one of the most trenchant expressions of our period's spirit. Soon after speaking this sentence into the tape recording of Gaines's "editor," Jane dies. But like the death of Aunt Fe in "Just Like a Tree," Jane's death marks a beginning rather than an end. With this last sentence, she expresses the end of the first great cycle of American life since emancipation. If the Robert Samsons are all but dead; if they do not dare to move into the unknown beyond their old limits; Alex and Jane are alive and they do dare to make that crucial move. And if whites learned nothing from the blacks for that hun- 
dred years, perhaps now, with the advent of a new life cycle, the black can teach the white to enter that cycle with a new vitality.

Jimmy Aaron, from the time of his birth, is thought by his people to be "the One," the leader, the incarnation of his people's aspirations. But only upon his death do his people realize they are ready for him. We are also ready for him, because Gaines has brought us through a century of growth. The nature of the new area into which Jane will move when she and her companions march into Bayonne is unknown. Perhaps it holds death. But that is the nature of life, and anyone who wants to live it completely must be prepared to die out of the old and be born into the new. The development of that preparedness in the spirits of the black American is the main subject of The Autobiography of Miss Jane Pittman, and the growth from death to life is its main lesson.

\section{FOOTNOTES}

1 Catherine Carmier (New York, 1964), p. 125.

2 Ibid., p. 129. All other page citations appear in parentheses after the quotation from the work indicated in the text of the essay. I have used the Bantam edition of Of Love and Dust and the Dial edition of Bloodline and The Autobiography of Miss Jane Pittman. 